\title{
地域在宅高齢者における運動習慣の継続と 心拍数の縦断変化
}

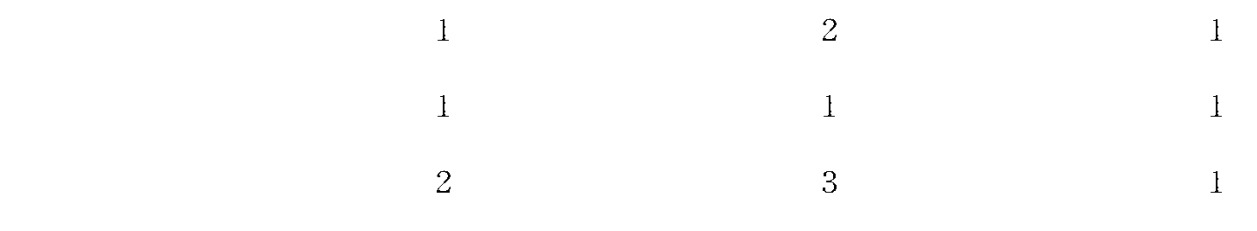

\section{EFFECT OF EXERCISE ADHERENCE ON LONGITUDINAL CHANGES IN HEART RATE AMONG COMMUNITY-DWELLING ELDERLY}

\author{
Yuko Yoshida, Shu Kumagai, Miho Sugiura, Taketo Furuna, \\ HidEyo Yoshida, HunKYung Kim, SHOJI SHINKAI, \\ SHUichiro WaTANABA and TAKaO SUZUKI
}

\begin{abstract}
Background: High heart rate (HR) has been associated with an increased risk of cardiovascular disease and mortality due to all causes. The present study was conducted to examine the effect of exercise adherence on longitudinal changes in resting heart rate among a population of community-dwelling elderly.

Methods: The subjects were 133 men and 209 women aged 65 and older who participated in a baseline survey in August 1992 and were subsequently followed annually for 8 years. Resting HR was measured in the sitting position. The independent variable was the longitudinal change in differences of $\operatorname{HR}(\Delta)$ from 1996 to 2000 . Dependent variables were age, heart rate, smoking habit, TMIG index of competence score, and states of exercise adherence during the period 1992-1996.

Results: Multiple regression analysis showed that heart rate in 1996 and smoking in men, and heart rate, TMIG index of competence score, and exercise adherence during the period 1992-1996 in women were significantly associated with longitudinal change in HR.

Conclusion: Exercise adherence reduced the increase in HR of elderly women. These results suggest the importance of exercise adherence in elderly women.
\end{abstract}

(Jpn. J. Phys. Fitness Sports Med. 2005, 54 : 295 -304)

key word : Heart rate, longitudinal change, community-dwelling elderly, exercise adherence

\section{I . 緒 言}

わが国の高齢者数は増加の一途をたどり，高齢者 の QOL や健康寿命の延伸に関心が向けられてい る . 高齡者の生活機能は体力により規定される部分 が大きく，健康で自立した生活を送るためには，体 力の維持は欠かせない要素の一つである ${ }^{1,2)}$ ，光の ため，普段から運動習慣を身につけ身体活動量を高 く維持することが重要であり，地域における保健施 策の提案にあたっては，高龄期の体力低下を遅延さ
せる手段やシステムの開発が急務である .

これまでの報告では，高齢者の体力指標として， 筋力，バランス能力，および，歩行機能などを取り 上げ，歩行能力が IADL や死亡の予測因子である こと ${ }^{1)}$ ，転倒発生の予測因子 ${ }^{2)}$ であることが確認さ れており，体力が高齢期における健康状態の予測因 子であることが示されている .

一方，体力指標として心拍数もあげられる.心拍 数は心肺機能や身体活動量との相関も高く，運動強 度の設定などに幅広く用いられている ${ }^{3,4)}$.また，

1)東京都老人総合研究所 疫学・福祉・政策研究グループ 干173-0015 東京都板橋区栄町35-2

2)東京都老人総合研究所 地域保健研究グループ 干173-0015 東京都板橋区栄町35-2

3)桜美林大学大学院 国際学研究科 老年学専攻 干194-0294 東京都町田市常盤町3758

Department of Epidemiology and Health Promotion, Tokyo Metropolitan Institute of Gerontology Department of Community Health, Tokyo Metropolitan Institute of Gerontology Major in Gerontology, Graduate School of International Studies, Obirin University 
高い心拍数が高齢期の心疾患の発生や心疾患による 死亡，および，高齢女性における骨折発生のリスク を高める独立した危険因子であることが示されてい $3^{5 \sim 12)}$. すなわち, 心拍数は高齢期の健康状態を 規定する要因の一つであり，心拍数の関連要因を探 索することは大きな意義があると考えられる．

また，安静時心拍数は持久的な運動により徐脈化 するが，これは運動が自律神経系に作用し副交感神 経優位になることに起因することが先行研究で説明 されている ${ }^{13 \sim 18)}$.このように心拍数は運動の実施 により影響を受けることが報告されている．

しかしながら, 先行研究における健康指標と心拍 数の関係についての報告では，心拍数を独立変数と して取り扱っているものが多く ${ }^{5 \sim 12)}$, 加えて，心 拍数の縦断的な変化に及ぼす因子について検討した 報告は少ない，本研究は，地域在宅高齢者を対象に 加齢に伴う心拍数の縦断変化に及ぼす運動習慣の継
続状況の影響について明らかにすることを目的とし た。

\section{II. 対象と方法}

\section{A. 対 象}

対象は秋田県南外村に在住する65歳以上の高齢者 であった。調査対象である秋田県南外村は県中央 の山間にある農村であり，農業を主な産業として いる．90年の国勢調査に基づく人口は5136名(男性 2446名,女性2690名)であった .本研究の対象は1992 年の 6 月 1 日時点で特別養護老人ホーム入所者を除 く65歳以上の村内に在住する高齢者934名 (男性375 名, 女性559名)である .ベースライン調査は1992年 に実施され，同樣の調査方法を用いた追跡調査は 4 年後の1996年，および 8 年後の 2000 年に実施され た.

$$
\text { ベースライン調査の参加状況と追跡調査時の転帰 }
$$

Table 1. Number of participants during the follow-up period.

\begin{tabular}{|c|c|c|c|c|}
\hline & & Men (\%) & Women $(\%)$ & Total $(\%)$ \\
\hline \multirow[t]{2}{*}{ Baseline survey in 1992} & Subjects & 375 & 559 & 934 \\
\hline & Respondents & $300(80.0)$ & $448(80.1)$ & $748(80.1)$ \\
\hline \multicolumn{5}{|l|}{ Follow-up survey in $1996 *$} \\
\hline & Respondents & $230(76.7)$ & $372(83.0)$ & $602(80.5)$ \\
\hline & Rejects & $1(0.3)$ & $0(0.0)$ & $1(0.1)$ \\
\hline & Institutionalized & $10(3.3)$ & $15(3.3)$ & $25(3.3)$ \\
\hline & Long-term absent & $1(0.3)$ & $4(0.9)$ & $5(0.7)$ \\
\hline & Death (cumulative) & $41(13.7)$ & $39 \quad(8.7)$ & $80(10.7)$ \\
\hline & Other, home visit & $17(5.7)$ & $18(4.0)$ & $35 \quad(4.7)$ \\
\hline & Short-term absent & $0(0.0)$ & $0(0.0)$ & $0(0.0)$ \\
\hline \multicolumn{5}{|l|}{ Follow-up survey in $2000 *$} \\
\hline & Respondents & $190(63.3)$ & $314(70.1)$ & $504(67.4)$ \\
\hline & Rejects & $0 \quad(0.0)$ & $1(0.2)$ & $1(0.1)$ \\
\hline & Institutionalized & $9(3.0)$ & $18(4.0)$ & 27 (3.6) \\
\hline & Long-term absent & $3(1.0)$ & $20(4.5)$ & $23(3.1)$ \\
\hline & Death (cumulative) & $98(32.7)$ & $90(20.1)$ & $188(25.1)$ \\
\hline & Other & $0(0.0)$ & $1(0.2)$ & $1(0.1)$ \\
\hline & Short-term absent & $0(0.0)$ & $2(0.4)$ & $2(0.3)$ \\
\hline & Unknown & $0 \quad(0.0)$ & $2(0.4)$ & $2(0.3)$ \\
\hline Subjects of this analysis & & $133(44.3)$ & $209(46.8)$ & $342(45.7)$ \\
\hline
\end{tabular}


を table 1 に示した . 1992年のベースライン調査に は同年村内在住の男性 375 名中 300 名 (参加率 $80.0 \%$ )，女性 559 名中 448 名 (参加率 $80.1 \%$ )の計 748 名が参加した .1992年のベースライン調査参加者 748 名 (男性300名, 女性448名)における追跡調査参加率 は1996年時で男性 $76.7 \%$ (230名)，女性 $83.0 \%$ (372 名）,2000年時で男性63.3\% (190名)，女性70.1\% (314 名)であった .ベースライン調査参加者748名の追跡 期間中の死亡数は ,1996年までに男性41名(13.7\%)， 女性 39 名 (8.7\%)の計80名 (10.7\%)であり，2000年 までには男性 98 名 (32.7\%)，女性 90 名(20.1\%)の計 188名 $(25.1 \%)$ が確認された .

本研究における分析対象者は, 1992年に実施され たベースライン調査参加者748名のうち，1992年か ら1996年の運動の実施状況が欠測し，また1996年お よび2000年の心拍数データに欠測值がある402名， ペースメーカー使用者 4 名を除いた男性133名 (平均 年齢 $73.7 \pm 4.2$ 歳)，女性 209 名 (平均年齢 $74.3 \pm 4.5$ 歳)とした。

本研究は, 東京都老人総合研究所の長期プロジェ ク卜研究「中年からの老化予防総合的長期追跡研究」 の一環として行われており, 調査方法 , ならびに光 の項目等については先行論文 ${ }^{19)}$ に詳細に記載され ている.また，本研究は当研究所の倫理委員会の審 査を経て実施され，対象者には研究の主旨と個人情 報の保護について十分な説明を行い，研究協力の同 意を得た。

\section{B. 分析項目}

本研究の分析項目は, 基本属性として性, 年齢, 医学的健診項目として, 収縮期血圧, 拡張期血圧, 心拍数, 血清アルブミン, 総コレステロール, HDL コレステロール，降圧剂の使用状況（あり，なし）， 心電図所見 (正常範囲, 要経過観察, 要精査), 身体 機能の項目として, 握力, 通常歩行速度, 最大歩行 速度を取り上げた . 光の詳細については先に報告し ている ${ }^{1,2,19,20)}$.

また，聞取り調査項目から，高次生活機能の指標 である老研式活動能力指標 $(13 \text { 点満点 })^{21)}$, 生活習 慣の状況を飲酒状況，喫煙状況，および一日に吸う 本数, 運動習慣を取り上げ, 飲酒状況については「飲 む」,「やめた」,「以前から飲まない」, 喫煙状況に ついては「吸う」,「やめた」,「以前から吸わない」,
運動習慣については「運動している」「運動してい ない」に分類し聞取りを行った .

運動については種目を問わず本人が運動と認識し ている身体活動とした．また運動習慣についての回 答は「運動している」「運動していない」の二つを 設けているが，分析にあたり，運動習慣の継続状況 を把握するため，1992年，1994年，1996年を通して 運動習慣の設問に対して「運動していない」と回答 している場合を「運動なし」,「運動している・運動 していない」が混在する場合は「運動中断」, 1992 年から1996年を通して「運動している」と回答があ つた場合を「運動継続」の 3 群に再分類し解析を行 つた．

心拍数は座位にて安静ののち, 自動血圧計(日本 コーリン, BP-103i)を用いて約 5 分間隔で二回測 定した．測定には，技術経験ともに習熟した看護師 があたり，測定には細心の注意を払った．安静状態 を考慮し，解析では二回目の測定值を用い解析を行 った。

\section{C. 統計解析}

1996年における主要変数の比較のうち, 質的変数 については $\chi^{2}$ 検定，連続量，および1996年から 2000 年における心拍数の変化量の検定には, 運動習慣継 続状況 (群)を要因とする一元配置分散分析を用い， $\mathrm{F}$ 値が有意の場合には LSD 法による多重比較検定 を行った . 1996年から 2000 年の心拍数の差の検定に は群別に paired T-test を用いた.心拍数の縦断変 化に運動習慣が影響するか否かについては重回帰分 析を用いて検討した . 分析にあたり，従属変数には 1996年から2000年までの心拍数の変化量, 独立変数 には1992年から1996年までの運動習慣の継続状況を 取り上げ，さらに，基本属性として年齢，生活機能 レベルを調整するため老研式活動能力指標総合点, 1996年時点の心拍数の水準の差を調整するために心 拍数, 交絡因子を調整する目的で, 喫煙習慣, 降圧 剂の使用状況，心電図所見，いずれも1996年時の変 数を取り上げた。

心拍数には明らかな性差が認められるため ${ }^{22) ，}$ 解析は男女別に実施した . 統計学的有意水準は $5 \%$ 未満とした。 
III. 結果

table 2 に主要変数として1996年の年齢, 体格指 数, 収縮期血圧, 拡張期血圧, 総コレステロール, HDL コレステロール, 血清アルブミン , ヘモグロ ビン $\mathrm{Alc}$, 握力, 歩行速度, 老研式活動能力指標 得点，飲酒習慣，喫煙習慣，運動習慣，降圧剂，心 電図所見を示した .男性の平均年齢は $73.8 \pm 4.2$ 歳, 女性は74.3土4.5歳であった。

1996年の各変数を table 3-a , table 3-b に示した . 男性では年齢のみで有意差がみられ，運動なし群に 比へ運動中断群で高かった $(\mathrm{p}<0.05)$. 女性では， また，通常歩行速度，および，最大歩行速度に有意 差が見られ，運動なし，運動中断に比べ運動継続が 高かった(光れ光れ $\mathrm{p}<0.05)$.
男女別に平均心拍数を群間で比較したところ，女 性のみで有意差が見られた(table 4)．1996年の心拍 数は, 運動なし群, 運動継続群に比へ運動中断群で 有意に高かった $(p<0.05) .2000$ 年の心拍数は, 運 動継続群に比べ, 運動なし群, 運動中断群で高かっ た $(\mathrm{p}<0.05)$.

次いで, 平均心拍数を 1996 年と 2000 年で比較する と, 全体の平均心拍数は女性のみで有意差がみられ， 1996年に比べ2000年で高かった $(\mathrm{p}<0.001)$. また， 運動習慣別に平均心拍数を比較すると, 女性の運動 なし群で1996年より2000年が高かった $(\mathrm{p}<0.001)$.

1996年から 2000 年における 4 年間の心拍数の変化 量を群間で比較すると，女性のみで有意差がみられ， 運動なし群 ( $4.3 \pm 10.6$ 拍/分の増加)に比へ, 運動 中断群 $(0.3 \pm 10.9$ 拍 $/$ 分の減少), 運動継続群 ( 1.2

Table 2. Characteristics for participants in 1996.

\begin{tabular}{|c|c|c|}
\hline & $\operatorname{Men}(n=133)$ & Women $(n=209)$ \\
\hline Age (years; mean $\pm S D$ ) & $73.8 \pm 4.2$ & $74.3 \pm 4.5$ \\
\hline Body mass index $\left(\mathrm{kg} / \mathrm{m}^{2} ;\right.$ mean $\left.\pm \mathrm{SD}\right)$ & $22.4 \pm 2.8$ & $23.1 \pm 3.4$ \\
\hline Systolic blood pressure $(\mathrm{mmHg}$; mean $\pm \mathrm{SD})$ & $142.5 \pm 21.9$ & $144.5 \pm 22.9$ \\
\hline Diastolic blood pressure $(\mathrm{mmHg}$; mean $\pm \mathrm{SD})$ & $77.5 \pm 10.3$ & $76.5 \pm 10.5$ \\
\hline Total cholesterol (mg/dl;mean \pm SD) & $171.9 \pm 31.3$ & $199.9 \pm 32.2$ \\
\hline HDL cholesterol (mg/dl; mean $\pm S D)$ & $50.1 \pm 12.7$ & $52.3 \pm 13.2$ \\
\hline Serum albumin (g/dl;mean $\pm S D)$ & $4.02 \pm 0.21$ & $4.14 \pm 0.20$ \\
\hline $\mathrm{HbA} 1 \mathrm{c}(\% ;$ mean $\pm \mathrm{SD})$ & $5.7 \pm 0.6$ & $5.8 \pm 0.7$ \\
\hline Hand grip (kg;mean $\pm S D)$ & $33.3 \pm 6.2$ & $21.2 \pm 4.6$ \\
\hline Normal walking speed $(\mathrm{m} / \mathrm{s} ;$ mean $\pm S D)$ & $1.20 \pm 0.22$ & $1.06 \pm 0.25$ \\
\hline Maximum walking speed (m/s; mean $\pm S D)$ & $1.91 \pm 0.37$ & $1.57 \pm 0.36$ \\
\hline TMIG-Index of Competence score (score; mean \pm SD) & $12.1 \pm 1.3$ & $11.3 \pm 2.0$ \\
\hline \multicolumn{3}{|l|}{ Current drinking $(\%)$} \\
\hline current & 61.7 & 19.6 \\
\hline past & 11.3 & 4.8 \\
\hline never & 27.1 & 75.6 \\
\hline \multicolumn{3}{|l|}{ Current smoking (\%) } \\
\hline current & 35.3 & 1.9 \\
\hline past & 28.6 & 1.0 \\
\hline never & 36.1 & 97.1 \\
\hline \multicolumn{3}{|l|}{ Regular physical activity (\%) } \\
\hline sedentary & 78.2 & 83.3 \\
\hline regularly & 21.8 & 16.7 \\
\hline \multicolumn{3}{|l|}{ Hypotensive drug use (\%) } \\
\hline use & 40.6 & 41.6 \\
\hline non-use & 59.4 & 58.4 \\
\hline \multicolumn{3}{|l|}{ Electrocardiography $(\%)$} \\
\hline normal & 36.1 & 34.9 \\
\hline need for follow-up & 45.9 & 45.9 \\
\hline need for detailed examination & 18.0 & 19.1 \\
\hline
\end{tabular}


Table 3-a. Comparison of characteristics for men between the groups in 1996.

\begin{tabular}{|c|c|c|c|}
\hline & \multicolumn{3}{|c|}{ State of exercise } \\
\hline & $\begin{array}{l}\text { sedentary } \\
\qquad(n=94)\end{array}$ & $\begin{array}{c}\text { sedentary } \\
\text { /regularly } \\
(n=22)\end{array}$ & $\begin{array}{l}\text { regularly } \\
\qquad(n=17)\end{array}$ \\
\hline Age (years; mean $\pm S D$ ) & $73.2 \pm 3.8$ & $75.5 \pm 6.0$ & $74.9 \pm 3.2 *$ \\
\hline Body mass index $\left(\mathrm{kg} / \mathrm{m}^{2} ;\right.$ mean $\left.\pm \mathrm{SD}\right)$ & $22.2 \pm 2.8$ & $22.1 \pm 2.8$ & $24.0 \pm 2.8$ \\
\hline Systolic blood pressure $(\mathrm{mmHg} ;$ mean $\pm \mathrm{SD})$ & $140.5 \pm 21.7$ & $150.2 \pm 24.9$ & $143.9 \pm 17.3$ \\
\hline Diastolic blood pressure $(\mathrm{mmHg} ;$ mean $\pm \mathrm{SD})$ & $76.4 \pm 9.8$ & $80.4 \pm 12.3$ & $79.5 \pm 9.4$ \\
\hline Total cholesterol $(\mathrm{mg} / \mathrm{dl} ;$ mean $\pm \mathrm{SD})$ & $172.0 \pm 30.5$ & $172.9 \pm 36.1$ & $170.1 \pm 30.7$ \\
\hline $\mathrm{HDL}$ cholesterol (mg/dl; mean $\pm \mathrm{SD})$ & $50.7 \pm 12.9$ & $48.0 \pm 13.0$ & $49.3 \pm 11.7$ \\
\hline Serum albumin $(g / d l ;$ mean $\pm S D)$ & $4.02 \pm 0.21$ & $4.00 \pm 0.25$ & $4.02 \pm 0.15$ \\
\hline $\mathrm{HbA1c}(\% ;$ mean $\pm \mathrm{SD})$ & $5.74 \pm 0.58$ & $5.61 \pm 0.50$ & $5.66 \pm 0.51$ \\
\hline Hand grip $(\mathrm{kg} ;$ mean $\pm S D)$ & $33.5 \pm 6.2$ & $31.7 \pm 6.5$ & $34.1 \pm 5.4$ \\
\hline Normal walking speed $(\mathrm{m} / \mathrm{s} ;$ mean $\pm \mathrm{SD})$ & $1.22 \pm 0.22$ & $1.10 \pm 0.21$ & $1.21 \pm 0.19$ \\
\hline Maximum walking speed $(\mathrm{m} / \mathrm{s} ;$ mean $\pm \mathrm{SD})$ & $1.93 \pm 0.38$ & $1.78 \pm 0.34$ & $1.97 \pm 0.32$ \\
\hline TMIG-Index of Competence score (score; mean \pm SD) & $12.1 \pm 1.2$ & $11.9 \pm 1.7$ & $12.3 \pm 0.8$ \\
\hline \multicolumn{4}{|l|}{ Current drinking (\%) } \\
\hline current & 58.5 & 63.6 & 76.5 \\
\hline past & 9.6 & 22.7 & 5.9 \\
\hline never & 31.9 & 13.6 & 17.6 \\
\hline \multicolumn{4}{|l|}{ Current smoking (\%) } \\
\hline current & 36.2 & 27.3 & 41.2 \\
\hline past & 28.7 & 22.7 & 35.3 \\
\hline never & 35.1 & 50.0 & 23.5 \\
\hline \multicolumn{4}{|l|}{ Hypotensive drug use (\%) } \\
\hline use & 35.1 & 54.5 & 52.9 \\
\hline non-use & 64.9 & 45.5 & 47.1 \\
\hline \multicolumn{4}{|l|}{ Electrocardiography $(\%)$} \\
\hline normal & 37.2 & 40.9 & 23.5 \\
\hline need for follow-up & 45.7 & 36.4 & 58.8 \\
\hline need for detailed examination & 17.0 & 22.7 & 17.6 \\
\hline
\end{tabular}

\pm 9.8 拍／分の減少)で有意に変化量が少なかった $(\mathrm{p}<0.05)($ table 4$)$.

N. 考 察

1996年から2000年の心拍数の変化に運動習慣が関 連するか否かを明らかにするため重回帰分析を行っ た (table 5). 分析モデルの決定係数 $\left(R^{2}\right)$ は, 男性 0.270 ，女性で0.165であった . 分析の結果，女性の みで運動習慣が有意な関連を示し $(p<0.01)$, 運動 習慣が持続している場合に心拍数の増加が抑制され ていた .

心拍数は健診などで広く用いられている医学指標 であり，測定方法も簡便である.また，心拍数は樣々 な疾病や死亡の予測因子であり，心拍数の増加に 伴い弚のリスクは増大することが報告されてい $3^{5 \sim 12)}$. しかし，心拍数が健康状態を知る上での 有用な予測因子であることは報告されているが，心 拍数の縦断変化に影響する因子についての報告は少 
Table 3-b. Comparison of characteristics for women between the groups in 1996.

\begin{tabular}{|c|c|c|c|}
\hline & \multicolumn{3}{|c|}{ State of exercise } \\
\hline & $\begin{array}{l}\text { sedentary } \\
\qquad(n=158)\end{array}$ & $\begin{array}{l}\text { sedentary } \\
\text { /regularly } \\
(n=30)\end{array}$ & $\begin{array}{l}\text { regularly } \\
\qquad(n=21)\end{array}$ \\
\hline Age (years; mean $\pm \mathrm{SD}$ ) & $74.1 \pm 4.4$ & $75.0 \pm 5.2$ & $74.6 \pm 4.0$ \\
\hline Body mass index $\left(\mathrm{kg} / \mathrm{m}^{2} ;\right.$ mean $\left.\pm \mathrm{SD}\right)$ & $23.2 \pm 3.4$ & $23.3 \pm 3.5$ & $22.5 \pm 3.3$ \\
\hline Systolic blood pressure $(\mathrm{mmHg} ;$ mean $\pm S D)$ & $143.5 \pm 22.1$ & $150.8 \pm 23.7$ & $143.3 \pm 27.4$ \\
\hline Diastolic blood pressure $(\mathrm{mmHg} ;$ mean $\pm \mathrm{SD})$ & $75.9 \pm 10.3$ & $80.1 \pm 11.7$ & $75.3 \pm 9.5$ \\
\hline Total cholesterol $(\mathrm{mg} / \mathrm{dl} ;$ mean $\pm \mathrm{SD})$ & $200.7 \pm 33.6$ & $201.1 \pm 28.5$ & $192.1 \pm 26.5$ \\
\hline HDL cholesterol (mg/dl; mean $\pm S D)$ & $52.6 \pm 13.5$ & $49.4 \pm 12.1$ & $54.2 \pm 12.6$ \\
\hline Serum albumin $(g / d l ; m e a n \pm S D)$ & $4.14 \pm 0.21$ & $4.14 \pm 0.17$ & $4.13 \pm 0.18$ \\
\hline $\mathrm{HbA1c}(\% ;$ mean $\pm \mathrm{SD})$ & $5.77 \pm 0.72$ & $5.75 \pm 0.61$ & $5.92 \pm 0.81$ \\
\hline Hand grip $(\mathrm{kg} ;$ mean $\pm \mathrm{SD})$ & $20.8 \pm 4.6$ & $22.0 \pm 5.3$ & $23.1 \pm 2.9$ \\
\hline Normal walking speed $(\mathrm{m} / \mathrm{s} ;$ mean $\pm \mathrm{SD})$ & $1.04 \pm 0.24$ & $1.08 \pm 0.29$ & $1.22 \pm 0.20 *$ \\
\hline Maximum walking speed $(\mathrm{m} / \mathrm{s} ;$ mean $\pm S D)$ & $1.54 \pm 0.35$ & $1.57 \pm 0.37$ & $1.83 \pm 0.32 *$ \\
\hline TMIG-Index of Competence score (score; mean \pm SD) & $11.3 \pm 2.0$ & $11.2 \pm 2.5$ & $11.8 \pm 1.1$ \\
\hline \multicolumn{4}{|l|}{ Current drinking (\%) } \\
\hline current & 19.6 & 23.3 & 14.3 \\
\hline past & 3.8 & 13.3 & 0.0 \\
\hline never & 76.6 & 63.3 & 85.7 \\
\hline \multicolumn{4}{|l|}{ Current smoking (\%) } \\
\hline current & 1.9 & 0.0 & 4.8 \\
\hline past & 0.0 & 3.3 & 4.8 \\
\hline never & 98.1 & 96.7 & 90.5 \\
\hline \multicolumn{4}{|l|}{ Hypotensive drug use (\%) } \\
\hline use & 39.9 & 46.7 & 47.6 \\
\hline non-use & 60.1 & 53.3 & 52.4 \\
\hline \multicolumn{4}{|l|}{ Electrocardiography $(\%)$} \\
\hline normal & 37.3 & 20.0 & 38.1 \\
\hline need for follow-up & 43.7 & 63.3 & 38.1 \\
\hline need for detailed examination & 19.0 & 16.7 & 23.8 \\
\hline
\end{tabular}

$* \mathrm{p}<0.05$ regularly $>$ sedentary, sedentary/regularly

ない. 乥こで, 本研究では, 地域に在住する高齢者 を対象に縦断的に実施した調査結果をもとに，運動 習慣の継続が心拍数の縦断変化に影響するか否かに ついて検討した .

本研究では，1992年から1996年における 4 年間の 運動状況を把握し，さらに关の後 4 年間の心拍数の 縦断変化への影響について検討を行った．弚の結果， 男女ともに全体の平均心拍数は1996年に比べ2000年 で高く，加齢に伴い増加を示した．また，運動習慣
の継続状況別に1996年および2000年の平均心拍数， 1996年から2000年までの心拍数の変化量を比較する と，女性のみで,群間に有意差が見られた(table 4). さらに, 心拍数の縦断変化と運動習慣の関連を検討 するため, 心拍数に影響する因子を調整因子として 投入し重回帰分析を実施したところ，女性において 運動習慣の継続が心拍数の変化量に影響し, 運動が 心拍数の縦断的な増加を抑制することが示された (table 5). 本研究で得られた結果は, 女性において 
Table 4. Longitudinal changes of heart rate between 1996 and 2000 .

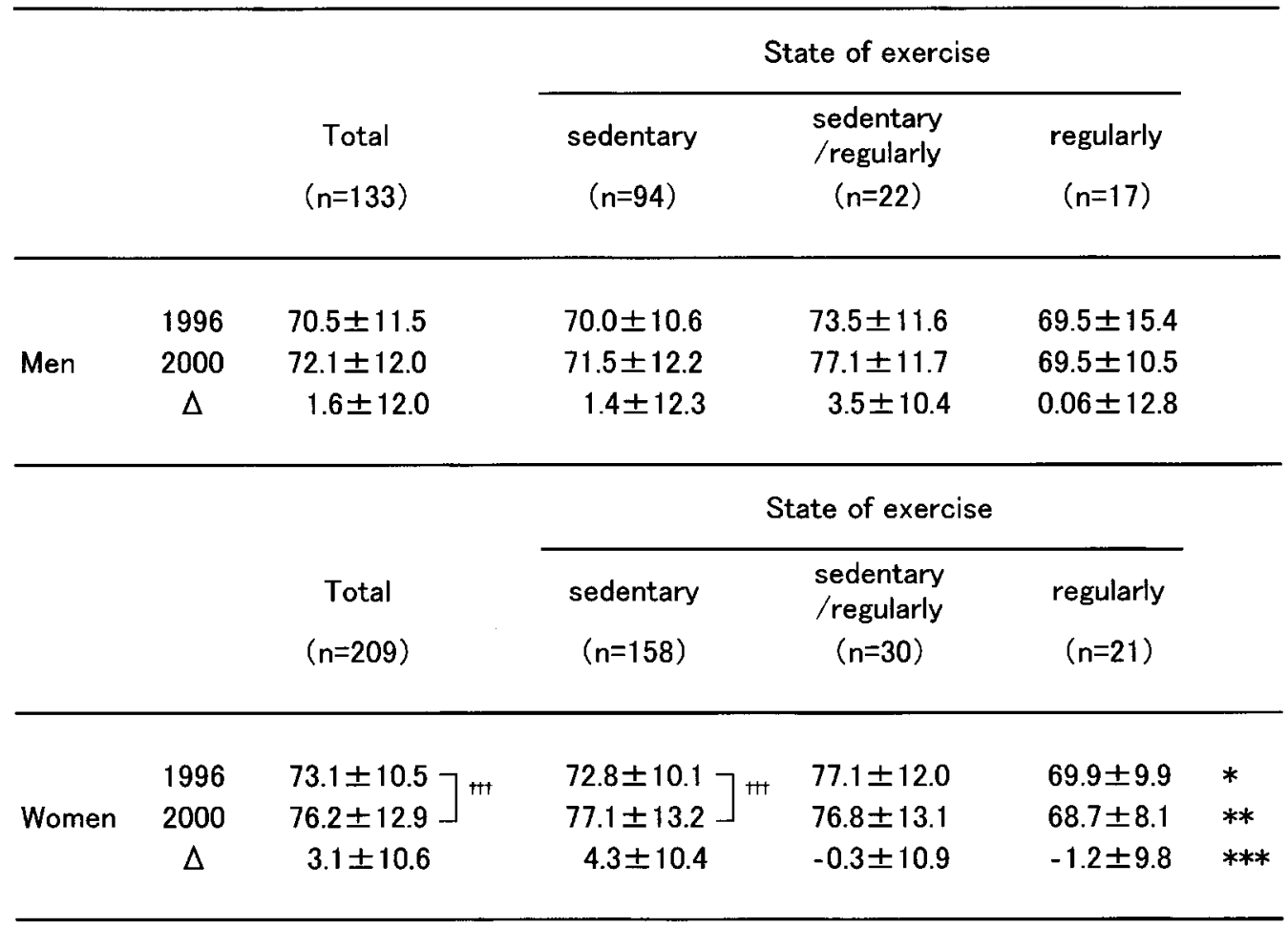

(mean $\pm \mathrm{SD}$, unit : beat $/ \mathrm{min}$ )

$1+t_{p}<0.001$ Comparison of longitudinal change in heart rate.

$* \mathrm{p}<0.05$ sedentary/regularly $>$ sedentary, regularly

$* * p<0.05$ sedentary, sedentary/regularly $>$ regularly

$* * * p<0.05$ sedentary $>$ sedentary/regularly, regularly

Table 5. Multile regression analysis for differences in heart rate from 1996 to 2000.

\begin{tabular}{lcc}
\hline & Men & Women \\
\cline { 2 - 3 } & \multicolumn{1}{c}{$\beta$} & $\beta$ \\
\hline Age & 0.060 & -0.102 \\
Heart rate & $-0.440 * * *$ & $-0.226 * * *$ \\
TMIG-index score & -0.020 & $-0.224 * *$ \\
Hypotensive drug use & 0.053 & 0.092 \\
Electrocardiography & -0.030 & 0.119 \\
Current smoking & $0.185 *$ & 0.061 \\
State of exercise & 0.005 & $-0.171 * *$ \\
\hline $\mathrm{R}^{2}$ & 0.270 & 0.165 \\
\hline
\end{tabular}

Relationship of exercise from 1992 to 1996 and the longitudinal change in differences of heart rate $(\Delta)$ from 1996 to 2000 , adjusted for age, heart rate, TMIG-index score, hypotensive drug use, electrocardiography, and current smoking in 1996. $* \mathrm{p}<0.05, * * \mathrm{p}<0.01, * * * \mathrm{p}<0.001$

過去の運動習慣の継続が，乥の後の心拍数の縦断変 化に作用していることを示した .

本研究では1996年から2000年で縦断的な心拍数の 増加が見られた . 心拍数と加齢に伴う変化について はいくつか報告がなされている．1〜74歳を対象に した横断研究 ${ }^{22)}$, および, 18〜79歳を対象にした
横断研究では, 加齢に伴う心拍数の変化はないこと が報告されている23)．また，10〜99歳を対象にし た横断研究では, 加齢に伴い心拍数は低下すること が報告されている24).また，これとは対照的に，64 歳以上を対象にした縦断調査では加齢に伴い心拍数 は増加することが報告されている ${ }^{25)}$ など結果は一 
致しない．これは，研究の方法や対象の違いが考え られるが , この点については今後明らかにしていく 必要がある。

先行研究によると持久的な運動の継続により，心 拍数が低下することが報告されている ${ }^{13 \sim 18)}$.これ は持久的な運動が自律神経活動に影響し，副交感神 経優位になることに起因する .これら先行研究の多 くは, 運動強度や頻度，期間を厳密に調整し，一定 強度以上の運動条件で害施される laboratory-based による報告が多い．また，自己管理型の運動の影響 について報告されている中高年者を対象とした在宅 型のトレーニングの実施による検討では，中強度の 運動でも心肺機能は改善し, 安静時の心拍数は低下 することが報告されている ${ }^{26)}$.このように，心拍 数の低下には持久的な運動のみではなく，自己管理 型の運動でも心肺機能に影響を及ぼすことが示され ている .

本研究は長期縦断研究であり, 研究のデザインは 先行研究と異なる。また, 運動の種類や強度, 頻度 なども一定ではない . しかし , ベースラインの1992 年から1996年までの運動習慣の継続状況別に1996 年，および2000年の心拍数の差を比較すると，女性 においてのみ，運動なし群では心拍数の増加がみら れたが, 運動中断群, 運動継続群では増加は認めら れず, 運動が心拍数の経時的な变化に影響している ことが示された．さらに，年齢や心拍数に影響する 因子を調整した上で分析を行っても，運動習慣の継 続は4年間後の心拍数に影響を及ぼしており，運動 の効果は比較的長期にわたり継続することが示され た .これは高齡期における運動効果の重要性を示す 知見であり，さらに精査する必要がある .

また，心拍数に対する運動の影響は女性のみで確 認された .これは, 男性に比べ女性の体カレベルが 相対的に低く，より効果的に運動の継続状況が心拍 数の増加の抑制に作用したことが考えられる．本研 究では, 運動の継続状況別に体力指標についても比 較を行った，关の結果，女性における歩行速度は， 運動なし群，運動中断群に比べて運動継続群で高い 值を示したが, 男性ではこの差は認められなかった . つまり，本研究で用いた運動習慣は女性での加齢に 伴う体力低下を抑制できる運動強度であり，よって， 女性で見られたような運動効果を男性で得るために は, さらに強度や頻度の高い運動の実施が必要であ
ることが考えられる .この点については今後検討す べき点である .

他方，男性では，ベースラインの喫煙状況が心拍 数の変化に影響しており，喫煙がある場合に心拍数 の増加を抑制していた．一般的に喫煙により心拍数 は影響を受け，安静時心拍数は非喫煙者より喫煙者 で高い $22,27,28)$ という本研究の結果とは対極の報告 が多い. 喫煙に伴う心拍数の増加については, エピ ネフリンの増加や $\beta$-adrenoceptor の低下 ${ }^{29)}$, 交感 神経活動の増加や副交感神経活動の低下など，喫煙 により心拍調節機能が鈍化することに起因すると報 告されている．また，喫煙による死亡リスクの増加 はこの心周期のアンバランスにより引き起こされる など30)，喫煙が心機能に悪影響を及ぼすことが報 告されている．喫煙が心拍調節機能に何らかの影響 を及ぼしていることが考えられるが, 本研究の結果 の機序について言及することは難しい．

本研究の限界点についてであるが, 先ず, 心拍数 は服薬や心疾患などにより影響を受けため，乥れら のケースを排除して解析を実施することか望ましい 7).しかし，高齢者は降圧剂使用や不整脈などのケー スが非常に多く，本研究では，降圧剂使用者，不整 脈者などは除かず，分析にあたっては調整因子とし て降圧剂使用の有無, さらに，健診における心電図 所見を投入した上で解析を行った。

次に，対象地域では1996年から栄養に関する介入 事業を実施し, 介入により地域の栄養状態は改善し ている.このことをいまえると保健行動の変化によ る体カレベルの変化も考えられるが, 介入の内容は 一部の高齢者に講話を開くなど軽度なため, 本研究 における解析では炎の影響はわずかであると考えら れる .

また, 運動強度についてであるが, 本研究で用い た運動習慣は，面接調査において回答者本人が「運 動」と自覚するものとし聞き取りを実施した．本研 究では, 散歩・体操についても「ふだん散歩や軽い 体操をしていますか」と別項目で聞き取りしている が，本研究の「運動習慣」には含まれていない．同

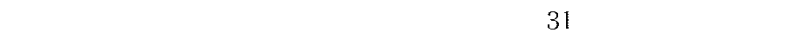
取り調査から「散歩・体操」群，「スポーツ」群，「運 動なし」群を分類し, 各種運動能力テストの結果を 合算し算出された得点を比較している. 谷の結果， 「スポーツ」群で兴の得点は最も高く，「運動なし」 
群と「散歩・体操」群では, 有意な相違がみられな いことが報告されている．これらの結果から，本研 究における「散歩・体操習慣」は体力に影響しない 強度と判断し, 身体活動の強度を一定レベル以上に するため「運動習慣」には含まずに解析を行った .

また，運動の内容であるが，1992年の運動の内容 は87\%がゲートボールであり，半数が週に $2 \sim 4$ 日 の運動頻度であると報告されている ${ }^{31)}$.このよう に, 本研究の運動は, 種目, 強度, 頻度ともに一定 ではないが，運動の効果が確認され，長期的な運動 の継続が炎の後の心拍数の増加を抑制したことが考 えられる .

V. 結 語

本研究の結果, 女性のみで長期的な運動の継続は その後の心拍数に影響し, 運動の効果は比較的長期 にわたり持続することを示していた．地域に在住す る高齢者を対象にした健康促進活動の展開には, 運 動は欠かせない取り組みの一つである．本研究の結 果は, 心拍数を指標とした高齢期の健康の維持には 運動が重要であることを再現し，高齢期の健康の維 持には運動を積極的に取り入れていくことの重要性 を示すものであった . また一方で，女性で認められ た運動の効果が男性ではみられないことから，男性 高齢者においては一定強度以上の運動実施が必要で あることが考えられた．本研究で得られた心拍数を 指標とした運動習慣の影響については，今後介入研 究により検証していく必要がある.

\section{謝 辞 \\ 本研究は東京都老人総合研究所プロジェクト「中年か らの老化予防総合的長期追跡研究」の一環として行われ た．本研究の実施にあたり秋田県南外村の皆樣，また， 東京都老人総合研究所疫学・福祉・政策研究グループ, 地域保健研究グループの方々, 他関係者各位に感謝しし 上げます．}

\section{(受理日 平成17年 5 月 16 日)}

\section{参 考 文 献}

1) 杉浦美穂, 長崎 浩, 古名丈人, 奥住秀之, 地域高 齢者の歩行能力 -4 年間の縦断変化一, 体力科学, (1998) , 47, 443-452.

2) Takao Suzuki, Hideyo Yoshida, Hunkyung Kim, Walking speed as a good predictor for maintenance of I-ADL among the rural community elderly in Japan :
A 5-year follow-up study from TMIG-LISA. Geriatrics and Gerontology International,(2003), 3, \$1-\$82.

3) Strath SJ, Swartz AM, Bassett DR Jr, O'Brien WL, King GA, Ainsworth BE. Evaluation of heart rate as a method for assessing moderate intensity physical activity. Med Sci Sports Exerc.(2000), 32, S465-70.

4) American College of Sports Medicine Position Stand, The recommended quantity and quality of exercise for developing and maintaining cardiorespiratory and muscular fitness, and flexibility in healthy adults. Med Sci Sports Exerc.(1998), 30, 975-91.

5) Seccareccia F, Pannozzo F, Dima F, Minoprio A, Menditto A, Lo Noce C, Giampaoli S. Heart rate as a predictor of mortality : the MATISS project. Am J Public Health.(2001), 91, 258-63.

6) Fujiura $Y$, Adachi H, Tsuruta M, Jacobs DR Jr, Hirai $\mathrm{Y}$, Imaizumi $\mathrm{T}$. Heart rate and mortality in a Japanese general population : an 18-year follow-up study. J Clin Epidemiol.(2001), 54, 495-500.

7) Kado DM, Lui LY, Cummings SR ; Study Of Osteoporotic Fractures Research Group. Rapid resting heart rate: a simple and powerful predictor of osteoporotic fractures and mortality in older women. J Am Geriatr Soc. (2002), 50, 455-60.

8) Benetos A, Thomas F, Bean K, Albaladejo P, Palatini P, Guize L. Resting heart rate in older people : a predictor of survival to age 85. J Am Geriatr Soc.(2003), 51, 284-5.

9) Chang M, Havlik RJ, Corti MC, Chaves PH, Fried LP, Guralnik JM. Relation of heart rate at rest and mortality in the Women's Health and Aging Study. Am J Cardiol.(2003), 1, 1294-9.

10) Perk G, Stessman J, Ginsberg G, Bursztyn M. Sex differences in the effect of heart rate on mortality in the elderly. J Am Geriatr Soc.(2003), 51, 1260-4.

11) Benetos A, Rudnichi A, Thomas F, Safar M, Guize L. Influence of heart rate on mortality in a French population : role of age, gender, and blood pressure. Hypertension.(1999), 33, 44-52.

12) Reunanen A, Karjalainen J, Ristola P, Heliovaara M, Knekt P, Aromaa A. Heart rate and mortality. J Intern Med.(2000), 247, 231-9.

13) Yamamoto K, Miyachi M, Saitoh T, Yoshioka A, Onodera S. Effects of endurance training on resting and post-exercise cardiac autonomic control. Med Sci Sports Exerc.(2001), 33, 1496-502.

14) Wilmore JH, Stanforth PR, Gagnon J, Rice T, Mandel S, Leon AS, Rao DC, Skinner JS, Bouchard C. Heart rate and blood pressure changes with endurance training: the HERITAGE Family Study. Med Sci Sports Exerc.(2001), 33, 107-16.

15) A. Levy WC, Cerqueira MD, Harp GD, Johannessen KA, Abrass IB, Schwartz RS, Stratton JR. Effect of endurance exercise training on heart rate variability at rest in healthy young and older men. Am J Cardiol. 
(1998), 15, 1236-41.

16) 山元健太, 高橋康輝, 吉岡 哲, 小野寺 昇, 宮地 元彦, 持久的トレーニングに伴う安静時徐脈と自律 神経系調節との関係,体力科学，(2001)，50，613-624

17) Leicht AS, Allen GD, Hoey AJ. Influence of intensive cycling training on heart rate variability during rest and exercise. Can J Appl Physiol.(2003), 28, 898-909.

18) Gregoire J, Tuck S, Yamamoto Y, Hughson RL. Heart rate variability at rest and exercise : influence of age, gender, and physical training. Can J Appl Physiol. (1996), 21, 455-70.

19) 柴田 博, 鈴木隆雄, 下中順子, 中年からの老化予 防プロジェクト(TMIG-LISA)の概要, 中年からの老 化予防・総合的長期追跡研究(TMIG-LISA)，東京都 老人総合研究所，(1997)，9-21.

20) 古名丈人, 長崎 浩, 伊藤 元, 橋詰 謙, 衣笠 隆, 丸山仁司，都市および農村地域における高齢者の運 動能力，体力科学，(1995)，44，347-356.

21) 古谷野 亘, 柴田 博, 中里克治, 芳賀 博, 須山 靖男, 地域老人における活動能力の測定一老研式活 動能力指標の開発一，日本公衆衛生杂隹誌，(1987），3， 109-114.

22) Gillum RF. Epidemiology of resting pulse rate of persons ages 25-74-data from NHANES 1971-74. Public Health Rep.(1992), 107, 193-201.

23) Monahan KD, Dinenno FA, Tanaka H, Clevenger CM, DeSouza CA, Seals DR. Regular aerobic exercise modulates age-associated declines in cardiovagal baroreflex sensitivity in healthy men. J Physiol. (2000), 1, 263-71.

24) Umetani K, Singer DH, McCraty R, Atkinson M. Twenty-four hour time domain heart rate variability and heart rate: relations to age and gender over nine decades. J Am Coll Cardiol.(1998), 1, 593-601 .

25) Tasaki H, Serita T, Irita A, Hano O, Iliev I, Ueyama C, Kitano K, Seto S, Hayano M, Yano K. A 15-year longitudinal follow-up study of heart rate and heart rate variability in healthy elderly persons. J Gerontol A Biol Sci Med Sci.(2000), 55, 744-9 .

26) Marshall P, Al-Timman J, Riley R, Wright J, Williams $S$, Hainsworth R, Tan LB. Randomized controlled trial of home-based exercise training to evaluate cardiac functional gains. Clin Sci.(2001), 101, 477-83.

27) Gerhardt U, Hans U, Hohage H. Influence of smoking on baroreceptor function : 24 h measurements. J Hypertens.(1999), 17, 941-6.

28) McVeigh GE, Morgan DJ, Finkelstein SM, Lemay LA, Cohn JN. Vascular abnormalities associated with long-term cigarette smoking identified by arterial waveform analysis. Am J Med.(1997), 102, 227-31.

29) Laustiola KE, Kotamaki M, Lassila R, Kallioniemi OP, Manninen V. Cigarette smoking alters sympathoadrenal regulation by decreasing the density of beta 2-adrenoceptors. A study of monitored smoking cessation. J Cardiovasc Pharmacol.(1991), 17, 923-8.

30) Srivastava R, Blackstone EH, Lauer MS. Association of smoking with abnormal exercise heart rate responses and long-term prognosis in a healthy, populationbased cohort. Am J Med.(2000), 109, 20-6.

31 ) 衣笠 隆, 長崎 浩, 地域高齢者の余暇身体活動と 健康状態及び機能的状態との関連, 中年からの老化 予防・総合的長期追跡研究 (TMIG-LISA), 東京都老 人総合研究所, (1997), 59-72. 